\title{
Impact of huminatrin on barley yield and quality in subtain zone of the Omsk region
}

\author{
Alyona Krasovskaya, Tatyana Veremey, Natalia Kudryavtseva, and SergeyZakharchenko ${ }^{1}$ \\ ${ }^{1}$ Omsk State Agrarian University named after P.A. Stolypin, g. Container, Institutskaya Square, 1, Omsk, 644008, Russia \\ ${ }^{2}$ Experimental and production organization "IP Poddubnaya A.V.", Office 110, D.9A, ul. Volkova, Omsk, 644045, \\ Russia
}

\begin{abstract}
The study of the impact of huminatrin on the yield and quality of barley grain in the subtaiga zone of the Omsk region on gray forest soils in 2019-2020 showed that the treatment of seeds and feeding of barley during the growing season with the fertilizer "Guminatrin" significantly increased the yield and protein content in the grain. The combination of increased productive tillering, the number of grains in a spikelet and the mass of 1,000 seeds contributed to the formation of the highest yield in the variants with seed treatment and fertilizing during the growing season with fertilizers "Universal huminatrin" with a high content of zinc and "Universal huminatrin" with an amino acid. The highest yield on average for 2 years of research equal to $5.08 \mathrm{t} / \mathrm{ha}$ was achieved by the use of the universal huminatrin fertilizer with high zinc content. Treatment of seeds and plants of barley during the growing season with huminatrin increased not only the yield but also the quality of the grain, specifically, the increased protein content.
\end{abstract}

\section{Introduction}

Currently, the creation, production and use of fertilizers based on humic acids in the cultivation of agricultural crops in various soil and climatic conditions is relevant. The effectiveness of these types of fertilizers is being widely studied in various regions of Russia. In the studies conducted by V.S. Vinogradova, A.A. Martyntseva, S.N. Kazarin on sod-podzolic mediumcultivated soils of the Kostroma and devoted to the effect of humic and micronutrient fertilizers on the yield of spring wheat, the morphophysiological processes of plants were activated, the productivity of the crop increased, and the indicators of grain quality improved. Thus, the highest yield was noted during the processing of seeds and crops, and the protein content in wheat grain increased to $14.0-14.2 \%$ versus $11.6 \%$ in the control [5]. Studies carried out in the Kemerovo region have shown that the use of humic preparations increases the yield and quality of oat grain [12]. The experiments of O.V. Shulepova, R.I. Belkina conducted in the conditions of the Northern Trans-Urals revealed that presowing treatment of barley seeds both with one dressing agent and in combination with the growth regulator Rostok (a preparation based on humic acids with a stimulating and anti-stress effect), contributed to an increase in the mass of 1,000 grains, grain nature and protein content [14].
Today, in the conditions of Western Siberia, huminatrin is one of the applied fertilizers based on humic acids and produced by OOO NPP Sibirskiye Gumaty. For grain crops, "Universal huminatrin" being a liquid fertilizer with a wide range of macro- and microelements is produced. The fertilizer is intended to stimulate the growth of crops and feed them in the main phases of development, to increase the effectiveness of protection against diseases, and to relieve stress when using pesticides. Thus, industrial and scientific experiments and research carried out in 2019 on wheat (Omsk Federal State Budgetary Scientific Institution "Omsk ANC", Federal Altai Scientific Research Institute of Agrobiotechnology, Kemerovo Scientific Research Institute of Agriculture, OOO Don-1 of the Altai Krai, experimental production farm "Mikhailovskoe" of the Krasnoyarsk Krai, etc.) showed a positive effect of huminatrin on increasing grain yield $[6,7,9]$. Therefore, it is relevant to study fertilizers based on humic acids in various soil and climatic conditions.

The purpose of the research is to study the effect of the universal huminatrin fertilizer and its experimental varieties on the yield and quality of barley in the subtaiga zone of the Omsk region.

\section{Research conditions and methods}

The experiments started in 2019-2020 at the educational and experimental site of the Department of Agronomy 
and Agroengineering of the Tara Branch of the Omsk State Agrarian University on gray forest soil with a neutral reaction of the environment, a high content of phosphorus, medium content of potassium regarding the grouping of soils according to Kirsanov [11], that is, the soil conditions were favorable enough for the cultivation of barley [13].

The growing season in 2019 (from May to September) was $1.5^{\circ} \mathrm{C}$ warmer compared to the longterm average data, the average daily air temperature was $14.8^{\circ} \mathrm{C}[2,3]$. Precipitation was slightly more $(13.3 \mathrm{~mm})$ than the norm and amounted to $303.3 \mathrm{~mm}$. Cold weather at the beginning of the growing season delayed the emergence of seedlings and the initial growth of barley, and warm, rather dry $2^{\text {nd }}-3^{\text {rd }}$ decades of July and $1^{\text {st }}-$ $2^{\text {nd }}$ August accelerated its filling and ripening, which contributed to obtaining a slightly smaller grain than it is typical for the studied variety [1].

The growing season in 2020 (from May to September) was on average much warmer with an average daily air temperature of $15.7^{\circ} \mathrm{C}$, which was $2.4^{\circ} \mathrm{C}$ higher than the average long-term data. Precipitation fell by $29 \mathrm{~mm}$ more than the norm being $319.0 \mathrm{~mm}[2,4]$. Thus, on average, May was very warm and with dry $1^{\text {st }}-2^{\text {nd }}$ decades and a rainy $3^{\text {rd }}$ decade, with almost 3 times more precipitation than the norm, which contributed to better barley tillering. June was cool, especially in the $2^{\text {nd }}$ and $3^{\text {rd }}$ decades with an average daily air temperature of 14.5 and $13.9^{\circ} \mathrm{C}$, respectively. July was generally hot and dry. The second decade of July with an average daily air temperature of $22.5^{\circ} \mathrm{C}$ was the hottest. The third decade was notable for the lack of precipitation, only $4 \mathrm{~mm}$ fell. The $1^{\text {st }}$ decade of August was characterized by hot and dry weather with an average daily air temperature of $22.8^{\circ} \mathrm{C}$ and $11 \mathrm{~mm}$ of precipitation, which contributed to the general barley ripening. The distribution of heat and precipitation in both years of research was uneven, which influenced the formation of elements of productivity and yield of barley.

The cultivar Sasha being a high-yielding variety in the conditions of Western Siberia was taken for the study. The variety was bred in SibNIISH by hybridization of varieties (Medicum 4396 x Medicum 4369) with subsequent individual selection. A type of medicum. Grain - large, yellow, filmy, semi-elongated. The weight of 1000 grains is $51.2 . .54 .0 \mathrm{~g}$, which is 5.1...7.7 $\mathrm{g}$ higher than that of the Omsk 91 variety. Grain flowability during sowing is good. The variety is medium-sized. Plants with a height of $70 \ldots 74 \mathrm{~cm}$ with a strong straw. The variety belongs to the steppe ecological group, drought-resistant, medium-ripe, from germination to maturation $74 \ldots 81$ days, characterized by high resistance to lodging. The variety is recommended for forage purposes. The maximum yield was obtained in 2015 in KSI SibNIISH - $6.4 \mathrm{t} / \mathrm{ha}$, the increase to the standard variety Omsk 91 was $1.8 \mathrm{t} / \mathrm{ha}$, on average for 5 years of testing (2011-2015) - 4.2 and $0.9 \mathrm{t} / \mathrm{ha}$, respectively [1]. The experiment was repeated four times, the placement of the plots was randomized.

The following options were studied:

1. Without treatment (control).
2. Seeds treatment $(21 / t)+$ double feeding with fertilizer "Universal huminatrin" at $2 \mathrm{l} / \mathrm{ha}$.

3. Seeds treatment $(21 / t)+$ double feeding with fertilizer "Universal huminatrin" with amino acid at 2 $1 /$ ha.

4. Seeds treatment $(21 / t)+$ double feeding with fertilizer "Universal huminatrin" with a high $\mathrm{Zn}$ content of 2 1/ha.

Foliar application was carried out in the following phases: tillering and heading.

The following agricultural technology was used in the experiment: the predecessor - grain and legumes. In autumn, moldboard tillage was carried out to the depth of the arable horizon. Harrowing and pre-sowing soil cultivation were carried out in the spring. The seeds were processed according to the experimental scheme. Sowing was carried out in the usual row method to the depth of 5 $\mathrm{cm}$ with a seeding rate of 5.5 million viable seeds per hectare. The care included rolling, spraying according to the test pattern and weed control. Harvesting was implemented at the end of the wax ripeness.

The recordings and observations were carried out according to the method of the State Variety Testing [8]: plot accounting of grain yield with data brought to $100 \%$ purity and standard moisture content; analysis of the structure of the crop. The protein content in grain was determined at the station of the Tarskaya agrochemical service in accordance with GOST 10846-91. Mathematical processing was carried out by the analysisof-variance method according to BA Dospekhov [10].

\section{Research results}

The findings showed that the treatment of seeds and crops with huminatrin as well as the weather conditions of the years of research influenced the formation of the barley grain yield.

The analysis of the yield structure showed that when using huminatrin, all plants were distinguished by greater height, productive tillering, number of grains per ear and size of seeds. In 2019, the tallest barley plants $(74.4 \mathrm{~cm})$ were on the variant treated with universal huminatrin with amino acid (Table 1 ), the $2^{\text {nd }}$ position in height was occupied by plants treated with universal huminatrin with an increased content of zinc $(73.4 \mathrm{~cm})$ and $3^{\text {rd }}$ position - universal huminatrin $(73.1 \mathrm{~cm})$. Plants in the control variant (without treatment) were the lowest $(66.2 \mathrm{~cm})$. In 2020, due to the combination of heat and moisture, the barley plants in all variants were distinguished by a greater height compared to 2019 . When treated with huminatrin, they were higher and, on average, over 2 years of research. The highest $(79.9 \mathrm{~cm})$ were the crops treated with universal huminatrin with amino acid, the lowest $(74.0 \mathrm{~cm})-$ on the control.

The highest productive tillering in 2019 (1.23) was when treating with universal huminatrin with an increased $\mathrm{Zn}$ content, somewhat less (1.19) - in the variant with universal huminatrine with amino acid, below (1.16) - when processing with universal huminatrin. The smallest productive bushiness (1.09) was in the control variant. A similar relationship was 
observed in 2020 when in all variants, the productive tillering of barley was higher due to the warmth and moisture availability in the $3^{\text {rd }}$ decade of May - the $1^{\text {st }}$ decade of June. The largest number of grains per ear was equal to 17.6 and 17.2 pieces in 2019 on the variants with the fertilizer treatment "Universal huminatrin" with an amino acid and "Universal huminatrin" with a higher $\mathrm{Zn}$ content, respectively, the smallest (15.9 pcs.) - on the variant without processing (Table 2). In 2020, the largest number of grains in an ear was 15.7 and 15.6 pieces on the $4^{\text {th }}$ and $2^{\text {nd }}$ options, respectively, the smallest (14.4 pcs.) on control. On average, over 2 years of research, the largest number of grains was 16.5 pieces formed on variants with feeding barley with fertilizer "Universal huminatrin" with an amino acid and high zinc content, the smallest (15.2 pcs.) - on the control variant without treatment.

Table 1. Plant height and productive tillering of barley

\begin{tabular}{|c|l|c|c|c|c|c|c|}
\hline \multirow{2}{*}{ No. } & \multicolumn{2}{|c|}{ Variant } & \multicolumn{3}{|c|}{ Plant height, cm } & \multicolumn{3}{c|}{ Productive bushiness } \\
\cline { 3 - 8 } & & 2019 & 2020 & On average & 2019 & 2020 & On average \\
\hline 1 & Without treatment (control) & 66.2 & 81.8 & 74.0 & 1.09 & 1.47 & 1.28 \\
\hline 2 & "Universal huminatrin" & 73.1 & 85.6 & 79.4 & 1.16 & 1.51 & 1.34 \\
\hline 3 & "Universal huminatrin" with amino acid & 74.4 & 85.4 & 79.9 & 1.19 & 1.56 & 1.38 \\
\hline 4 & "Universal huminatrin" with high Zn content & 73.4 & 85.2 & 79.3 & 1.23 & 1.59 & 1.41 \\
\hline
\end{tabular}

Treating seeds and crops with universal huminatrin with high zinc content provided the largest grain. The mass of 1,000 grains in that variant was the largest and amounted to $49.6 \mathrm{~g}$ in 2019 and $55.0 \mathrm{~g}$ in 2020 . The $2^{\text {nd }}$ and $3^{\text {rd }}$ by weight of 1,000 grains were the $3^{\text {rd }}$ and $2^{\text {nd }}$ variants, respectively. The smallest, with a mass of
1,000 grains of 47.7 and $51.3 \mathrm{~g}$ in 2019 and 2020, respectively, were seeds on the control variant. On average, for 2 years of research, the treatment of seeds and crops with universal huminatrin with high zinc content ensured the formation of the largest grain, which later affected the yield in the complex.

Table 2. Number of grains per ear and weight of 1,000 barley seeds

\begin{tabular}{|c|l|c|c|c|c|c|c|}
\hline \multirow{2}{*}{ No. } & \multicolumn{2}{|c|}{ Variant } & \multicolumn{3}{|c|}{ Number of grains per ear, pcs. } & \multicolumn{3}{c|}{ Weight of 1,000 seeds, g } \\
\cline { 3 - 8 } & & 2019 & 202 & On average & 2019 & 2020 & On average \\
\hline 1 & Without treatment (control) & 15.9 & 14.4 & 15.2 & 47.7 & 51.3 & 49.5 \\
\hline 2 & "Universal huminatrin" & 16.3 & 15.6 & 16.0 & 48.3 & 53.4 & 50.9 \\
\hline 3 & "Universal huminatrin" with amino acid & 17.6 & 15.4 & 16.5 & 48.8 & 54.1 & 51.5 \\
\hline 4 & "Universal huminatrin" with high Zn content & 17.2 & 15.7 & 16.5 & 49.6 & 55.0 & 52.3 \\
\hline
\end{tabular}

The combination of increased productive toughness, the number of grains in a spikelet and the weight of 1,000 seeds contributed to the formation of the highest yield on the variants with seed treatment and feeding for vegetation with fertilizers "Universal huminatrin" with a high content of $\mathrm{Zn}$ and "Universal huminatrin" with an amino acid. In 2019, the yield of barley grain on these variants was, respectively, 4.37 and $4.22 \mathrm{t} / \mathrm{ha}$ (Table 3 ) and was significantly higher not only the control but also the variant with the treatment with universal huminatrin. In 2020, variants with huminatrin treatment provided a significant increase in yield compared to the control. The highest yield (5.78 $\mathrm{t} / \mathrm{ha}$ ) was on the variant with the use of universal huminatrine with a high zinc content.

Table 3. Barley grain yield, t/ha

\begin{tabular}{|c|l|c|c|c|}
\hline \multirow{2}{*}{ No. } & \multirow{2}{*}{ Variant } & \multicolumn{3}{|c|}{ Yield, t/ha } \\
\cline { 3 - 4 } & & 2019 & 2020 & On average \\
\hline 1 & Without treatment (control) & 3.44 & 4.55 & 4.00 \\
\hline 2 & "Universal huminatrin" & 3.82 & 5.29 & 4.56 \\
\hline 3 & "Universal huminatrin" with amino acid & 4.22 & 5.46 & 4.84 \\
\hline 4 & $\begin{array}{l}\text { "Universal huminatrin" with high Zn } \\
\text { content }\end{array}$ & 4.37 & 5.78 & 5.08 \\
\hline & $\mathrm{HCP}_{05}$ & 0.217 & 0.172 & \\
\hline
\end{tabular}


Seed treatment and foliar feeding of barley plants during the growing season increased not only the yield but also the quality of the grain, specifically, the protein content. At the same time, in 2019, the highest protein content significantly different from the rest of the options $(19.4 \%)$ was provided by the option with the treatment of the universal huminatrin fertilizer with an amino acid (Table 4).
In other variants, the protein content was also higher compared to the control amounting to 15.6 and $15.9 \%$. The lowest content $(13.8 \%)$ was in the control variant. In 2020 , the highest protein content $(15.3 \%)$ was in the $3^{\text {rd }}$ variant, slightly lower content $(14.8 \%)-$ in the $4^{\text {th }}$ variant, the lowest $(13.1 \%)$ - in the first option.

Table 4. Protein content in barley grain, $\%$

\begin{tabular}{|c|l|c|c|c|}
\hline No. & \multirow{2}{*}{ Variant } & \multicolumn{3}{|c|}{ Protein content, \% } \\
\cline { 3 - 4 } & & 2019 & 2020 & On average \\
\hline 1 & Without treatment (control) & 13.8 & 13.1 & 13.5 \\
\hline 2 & "Universal huminatrin" & 15.6 & 13.6 & 14.6 \\
\hline 3 & "Universal huminatrin" with amino acid & 19.4 & 15.3 & 17.4 \\
\hline 4 & $\begin{array}{l}\text { "Universal huminatrin" with high Zn } \\
\text { content }\end{array}$ & 15.9 & 14.8 & 15.4 \\
\hline
\end{tabular}

On average, over 2 years of research, the highest protein content in grain was provided by the variant with seed treatment and foliar application "Universal huminatrin" with amino acid.

\section{Conclusions and recommendations}

Thus, on average for 2 years of research, seed treatment and feeding of barley during the growing season with fertilizers "Universal Huminatrin" with various additional components significantly increased the yield and protein content in the grain.

1. The highest grain yield of $5.08 \mathrm{t} / \mathrm{ha}$ was provided by the use of universal huminatrin fertilizer with a high zinc content, and in 2019 - universal huminatrin fertilizer with an amino acid and a high zinc content.

2. The highest protein content equal to $17.4 \%$ was obtained when using "Universal Huminatrin" with amino acid. On the variant with the use of huminatrin with increased zinc content, the protein content was also higher compared to the control and the use of the universal huminatrin fertilizer, which also provided an increase in protein in the grain as compared to the variant without treatment.

It is necessary to recommend the use of fertilizers of the "Universal Huminatrin" line in the cultivation of barley in the northern regions of the Omsk region in order to increase the yield and quality of grain.

\section{References}

1. P.V. Popolzukhin, P.N. Nikolaev, N.I. Aniskov et al. Achievements of science and technology of the agro-industrial complex, 33(1), 27-29, (2019)

2. Agroclimatic reference book on the Omsk region. (Leningrad: Gidrometeoizdat, 1959)

3. Agrometeorological bulletins of the HMS Tara of the Omsk region for May, June, July, August and September 2019. (Tara, 2019).
4. Agrometeorological bulletins of the HMS Tara of the Omsk region for May, June, July, August and September 2020. (Tara, 2020).

5. V.S. Vinogradova, A.A. Martyntseva, S.N. Kazarin Agriculture. 1, 32-34, (2015)

6. LLC «NPP Siberian humates» Huminatrine with trace elements. Fertilizer performance reports 2019. (Tomsk, 2019)

7. A.V. Krasovskaya, T.M. Veremey, N.N. Kudryavtseva Modern scientific knowledge in the context of systemic changes: materials of the Fourth National Scientific and Practical Conference, pp. 90-96 (Omsk: Publishing house of the Omsk GAU, 2020).

8. M.A. Fedin (ed). Methodology of state variety testing of agricultural crops. (Moscow, 1985).

9. R.V. Molkoedova Student science about topical problems and prospects of innovative development of the regional agro-industrial complex: materials of the XIX scientificpractical conference of students, p.19-22. (Omsk: Publishing house of the Omsk GAU, 2020)

10. V. F. Moiseychenko, M. F. Trifonova, A. Kh. Zaveryukha, V. E. Eshchenko Fundamentals of scientific research in agronomy (Moscow: Kolos, 1996).

11. P.M. Smirnov, E.A. Muravin Agrochemistry. (Moscow: Agropromizdat, 1991).

12. N.N. Chumanova, E.A. Egushova Agriculture. 3, 32-34, (2016)

13. D. Shpaara (Ed.) Cereal crops (Cultivation, harvesting, refinement and use) (Moscow: OOO DLV AGRODELO, 2016)

14. O. V. Shulepova, R.I. Belkina Bulletin of KrasGAU. 10, 9-14, (2017) 